\title{
O CORPO EM (DIS)CURSO: DOMINAÇÃO E RESISTÊNCIA NO CONTO DA AIA
}

\section{BODY IN DIS(COURSE): DOMINATION AND RESISTANCE IN THE HANDMAID TALE}

\author{
Ariane Silva da Costa Sampaio ${ }^{1}$ \\ [https://orcid.org/0000-0002-9415-622X] \\ Washington Silva de Farias ${ }^{2}$ \\ [https://orcid.org/0000-0003-0749-2469] \\ DOI: 10.30612/raido.v14i35.1163
}

RESUMO: O interesse pelo corpo, enquanto objeto do conhecimento, é tăo antigo quanto a civilizaçấo. Seus modos de representaçăo têm se transformado junto com as práticas discursivas que o definem, e com isso tem se mostrado elemento analítico das relaçôes sociais e objeto de representaçăo dos comportamentos, atitudes, moralidade, estética e ética de um determinado período sócio-histórico. Empreendemos nesse trabalho uma análise dos gestos de interpretaçâo acerca do corpo do sujeito mulher no livro 0 conto da Aia, de autoria de Margaret Atwood (1985 [2017]), e em sua adaptaçâo televisa criada por Bruce Miller em 2017. Teremos como base teórica e metodológica os estudos discursivos de Pêcheux (2014, 2015, 2016), Orlandi (2016) e Ferreira(2013). Buscaremos compreender, nas duas versôes, literária e fílmica, os modos de discursivizaçáo da dominaçâo e da resistência do/no corpo. Nessa perspectiva, dois funcionamentos discursivos seráo caracterizados: o do corpo dominado e o do corpo resistente, esse último se desdobrando em duas posiçôes: corpo-subsistência e corpo-erótico.

Palavras-Chave: Corpo; Discurso; Dominaçâo; Resistência; O Conto da Aia.

ABSTRACT: Interest in the body as an object of knowledge is as old as civilization. Its modes of representation have been transformed along with the discursive practices that defines. This contributed to present the body as an analytical element of social relations and as an object of representation for behaviors, attitudes, morality, aesthetics and ethics of a given socio-historical period. In this paper we undertake an analysis of interpretation gestures regarding woman subject body in the book The Handmaid's Tale by Margaret Atwood (1985 [2017]) and the television adaptation created by Bruce Miller in 2017. As theoretical and methodological framework we follow the discursive studies of Pêcheux (2014, 2015, 2016), Orlandi (2016) and Ferreira (2013). We aim to understand in both literary and filmic versions the discursive modes of domination

1 Mestranda no Programa de Pós-Graduaçâo em Linguagem e Ensino, na Universidade Federal de Campina Grande.

2 Professor Doutor do Programa de Pós-Graduaçăo em Linguagem e Ensino, na Universidade Federal de Campina Grande. 
and resistance of/in the body. In this perspective, two discursive functions are characterized: the one of the dominated body and the one of the resistant body, the latter unfolding in two positions: subsistence body and erotic body.

Keyworlds: Body; Discourse; Domination; Resistance; The Handmaid's tale.

\section{INTRODUÇÃO}

O corpo tem despertado o interesse dos mais diversos estudiosos ao longo de toda a história da civilizaçăo ocidental. Seja nas artes ou na ciência, o imaginário sobre o corpo tem se mostrado aspecto importante para a compreensâo das relaçôes humanas de uma determinada época e cultura. No campo das artes, a literatura é responsável por mobilizar as imagens construídas para esse corpo, seja ao representá-lo e/ou questioná-lo por meio de seus personagens e enredos. Enquanto lugar de simbologias, o corpo se mostra no literário como fonte de análise das relaçôes sociais de poder materializadas através das discursividades que circulam no exterior ficcional.

O livro objeto de nossa análise, O conto da aia, de autoria da canadense Margaret Atwood, foi publicado originalmente em 1985, com o título em inglês The Handmaid's Tale. Em 2017, o livro volta a ocupar lugar de destaque na mídia através da sua adaptaçăo televisiva na série homônima criada e dirigida por Bruce Miller e distribuída pelo serviço de streaming Hulu. As duas narrativas partem do ponto de vista da narradora-personagem Offred, que tem sua vida mudada completamente depois de um golpe de estado que transformou parte dos E.U.A em uma sociedade totalitária e teocrática, a República de Gilead.

As mulheres nessa nova forma sociopolítica săo rigidamente classificadas, por sua capacidade reprodutiva (Aias, mulheres aptas a reproduzirem; e as Esposas, mulheres casadas e da alta sociedade, mas que nâo podem ter filhos); por sua relaçăo com a moral religiosa (Aias, mulheres pecadoras; Esposas, mulheres casadas pela igreja e com homens da alta cúpula política; Tias, mulheres instruídas que se renderam ao regime autoritário e săo responsáveis por sua legalizaçăo e manutençâo, inclusive para treinamento das Aias; Econoesposas, mulheres casadas pela igreja com homens de classes socioeconômicas inferiores; Martas, mulheres que năo podem mais reproduzir, mas săo bem vistas pela moral religiosa, sendo responsáveis pela cozinha e arrumaçăo da casa das Esposas); por sua posiçáo de exclusâo (mulheres da Colônia, que nâo se submeteram ao regime e săo condenadas a trabalhar com lixo radioativo em condiçôes insalubres; mulheres da Casa de Jezebel, lugar de prostituiçăo que abriga mulheres que fugiram das casas em que serviam como Aias, mas que nâo foram levadas para a Colônia).

A relaçăo mulher e corpo permeia toda a obra literária e fílmica, retomando o imaginário sobre o corpo feminino como lugar de determinaçăo da capacidade do sujeito mulher, tăo debatido na atualidade e rejeitado pela discursividade feminista de autonomia do corpo feminino e da desnaturalizaçăo do gênero e da sexualidade. Tendo em vista o momento histórico de ascensâo do discurso conservador, principalmente no que tange ao sujeito mulher, acreditamos que a análise de $\mathrm{O}$ conto da aia se faz relevante por evidenciar como as relaçôes de poder podem agir sobre os corpos, convocando o sujeito leitor e espectador a assumir posiçōes acerca do assunto, ao transpor o discurso ficcional para o cotidiano, e suscitar questóes que dizem respeito à ordem política e social atual. 
Tendo isso em vista, nos propomos analisar o corpo como dispositivo de visualizaçăo do sujeito mulher (FERREIRA, 2013), buscando compreender a produçâo de efeitos de sentidos de dominação e de resistência, na sua relaçăo com o efeito erótico, no discurso literário e fílmico de $\mathrm{O}$ conto da aia, por meio da personagem Offred. Nossa análise evidenciou a representaçăo do corpo feminino produzido por dois funcionamentos discursivos: do corpo dominado e do corpo resistente, tendo esse último duas posiçóes possíveis: posiçăo de corpo-subsistência e a posiçăo corpo-erótico.

Entendendo o corpo como produto de uma rede de memória responsável pelo imaginário que constitui o sujeito mulher, iniciaremos nosso trabalho fazendo um percurso acerca dos sentidos produzidos para o corpo em condiçôes de produçấo sócio-históricas e ideológicas diversas, sentidos esses que ainda produzem efeitos nos discursos contemporâneos sobre a mulher.

\section{UMA REDE DE MEMÓRIAS E SENTIDOS SOBRE O CORPO}

Para pensarmos sobre a produçáo de sentidos acerca do corpo nas versôes literária e fílmica de $\mathrm{O}$ conto da Aia, mobilizamos a noçấo de memória discursiva. Sendo nosso escopo teórico a Análise do Discurso Pecheutiana, entendemos como memória todo dizer outro que retorna ao falarmos sobre algo, nesse caso o corpo. De acordo com Pêcheux (2015, p. 50), a memória é um "espaço móvel de divisōes, disjunçōes, de deslocamentos e de retomadas, de conflitos de regularizaçăo... um espaço de desdobramentos, de réplicas, polêmicas e contradiscursos". A memória é entăo o espaço de deslocamento, de contradiscursos e de polêmicas e năo uma esfera plana assemelhando-se a um reservatório em que os sentidos săo acumulados.

A memória atravessa o discurso pelo interdiscurso, entendido como "conjunto de formulaçôes feitas e esquecidas que determinam o que dizemos" (ORLANDI, 2015, p. 31). As palavras já fazem sentido antes da sua articulaçấo e o interdiscurso associa um discurso a outro, produzindo efeito de sentidos e inscrevendo os sujeitos em uma formaçăo discursiva e năo outra,

[...] porque os elementos da sequência textual funcionando em uma formaçáo discursiva dada, podem ser importados (meta-forizados) de uma sequência pertencente a uma outra formaçâo discursiva que as referências discursivas podem se construir e se deslocar historicamente (PÊCHEUX, 1984 [2016, p. 158]).

O funcionamento do discurso resulta da articulaçăo entre o interdiscurso e o intradiscurso, ou seja, de uma relaçăo entre a memória dos sentidos (o "dizível" do interdiscurso) - e atualidade do dizer - o dito.

Assim, sendo o corpo um objeto discursivo, está imbricado numa rede de memória que o identifica e delimita em sua historicidade, ou seja, que sustenta a mobilizaçăo política e ideológica de seus atributos em determinadas condiçōes de produçấo. Se pode afirmar entăo que o corpo do sujeito mulher, objeto de estudo deste trabalho, é produzido nos espaços de desdobramentos, polêmicas e contradiscursos da memória, como nos fala Pêcheux (2015). A memória do corpo, pois, nos remete a toda uma filiaçâo de dizeres que ressoam no corpo discursivo do sujeito mulher, demarcando as relaçóes de sentido e de poder que o atravessam. 
Nessa rede de memórias, os sentidos estabilizados para o corpo săo retomados pela discursividade escolhida pelo sujeito autor como crítica à submissáo do sujeito mulher numa sociedade patriarcal e esses sentidos se rompem/deslocam para produzir efeitos de sentidos de resistência àqueles que colocam numa posiçăo de sujeito dominado.

Nessa rede, partimos do conceito de corpo discursivo delimitado por Ferreira (2013), que o compreende tanto como uma linguagem como quanto uma forma de subjetivaçâo, e por isso vinculando-se ao discurso. Para a autora, o corpo, assim como a língua, é lugar de falha, de simbolizaçâo das marcas socioculturais e históricas. Desse modo, o corpo se coloca como objeto para a análise do discurso na sua relaçáo com o sujeito, a ideologia e o imaginário (FERREIRA, 2013). A partir do assujeitamento ideológico, na interpelaçăo do indivíduo em sujeito pela ideologia, por meio da relaçâo mundo, história e inconsciente, o corpo se constitui enquanto representaçăo desse sujeito do discurso e pelo imaginário construído em uma determinada conjuntura sócio-histórica produzindo posiçôes que se materializam no discurso.

Em seu processo de discursivizaçấo, conforme Ferreira (2013), o corpo mobiliza o dispositivo de visualizaçăo, ao possibilitar modos de ver o sujeito, tanto em relaçăo à cultura quanto à historicidade que o constituem como tal. O corpo que se expóe ao olhar e que olha, que se deixa manipular, que se estabelece como lugar do visível e do invisível (FERREIRA, 2013, p. 78). Ou seja, um corpo materializado pelo discurso e por isso suscetível a falhas, atravessado e constituído pela linguagem. A autora ainda diz que,

Esse corpo que fala seria também o corpo que falta, donde a inclusăo da noçăo de real do corpo, ao lado do real da língua e do real do sujeito. A exemplo do que singulariza o registro do real, o real do corpo seria o que sempre falta, o que retorna, o que resiste a ser simbolizado, o impossível que sem cessar subsiste (FERREIRA, 2013, p. 79, grifos da autora).

Entendendo o corpo pela sua historicidade e na sua relaçâo com a cultura e a língua, abordaremos a seguir discursos que simbolizam o corpo e o inscrevem nessa rede de memórias. $O$ primeiro deles é o discurso filosófico da antiguidade grega. Nele o corpo é idealizado e condicionado ao aprimoramento. 0 corpo belo era visto como elemento de glorificaçấo (BARBOSA et al, 2009) e tâo importante quanto a mente. Mente e corpo estariam em uma relaçăo de aprimoramento mútuo para servirem de objeto de admiraçăo. Ainda na Grécia antiga, o homem nu era a representaçáo da beleza e da saúde desse corpo aprimorado. Dessa forma, os gregos estabeleciam condutas apropriadas para o uso dos prazeres, como bebidas, para evitar excessos e descontroles sob o corpo. No entanto, a glorificaçăo e admiraçăo pelo corpo, assim como os cuidados regidos a ele eram destinados aos homens livres, excluindo escravos e mulheres. Às últimas, restavam-lhes a funçăo doméstica e submissáo ao patriarcado. O corpo era produzido e pensado no masculino.

O discurso cristăo da Idade Média marcou o corpo como fonte do pecado, devendo ser ocultado em respeito e obediência cristă. A metáfora de Adâo e Eva passa a significar a relaçaáo homem e corpo. O ideal de transcendência e negaçấo corpórea, simbolizados por Maria e Cristo, reelabora um novo estatuto para o corpo, ainda com base em uma determinada camada da populaçăo, a classe dominante, aristocrática e urbana, estabelecendo novos parâmetros de conduta comportamental e rigoroso 
controle social e ideológico exercido pela Igreja e pelas instituiçóes laicas que estavam ao seu serviço (DEL PRIORE, 1995). O corpo do sujeito mulher se constrói nessa rede de filiaçăo entre a dualidade santa e pecadora, a primeira, a representaçăo da mulher que todas deveriam ser - Maria, virgem imaculada - e a segunda, a representaçăo de como todas sâo - Eva, a pecadora (TEDESCHI, 2012).

Ainda na Idade Média, o discurso do/sobre o corpo é marcado pela rigidez dos valores morais estabelecidos pela Igreja juntamente com a Monarquia. O corpo representado como objeto terreno e material é contraposto à alma, vista como aprisionada pelo corpo, o qual deve ser purificado pela puniçăo (BARBOSA et al, 2009). Essa dualidade acarreta também as técnicas coercitivas sobre esse corpo, como os castigos e execuçóes públicas, o autoflagelo e as condenaçóes pelo Tribunal do Santo Ofício. Nesse período há ainda o que Federici (2017) chamou de "catecismo sexual", no qual a Igreja estabelecia as regras permitidas para o ato sexual, incluindo dias e posiçôes do ato sexual, bem como com quem eram ou nâo aceitas relaçôes sexuais.

Na Idade Moderna, o discurso renascentista do/sobre o corpo filia-se ao estatuto científico ao colocá-lo como objeto de estudo, de descriçáo e de análise. A ideia de dualidade corpo e alma ainda se mantém, mas se distancia da questăo religiosa, ao retratar o homem constituído por duas substâncias: uma pensante - a razăo, e a outra material - o corpo. Esse imaginário do ser constituído por sua parte física e outra subjetiva é instituído a partir das teorias do filósofo Descartes e se estende até o discurso iluminista do século XVIII. Nele, o corpo é depreciado, sendo-lhe negada a vivência sensorial e corporal, incorporando os sentidos de racionalidade como forma de dominaçấo (BARBOSA et al, 2009).

O discurso do/sobre o corpo é reconfigurado no final do século XIX, sob os efeitos dos discursos filosóficos e o psicanalítico. No discurso filosófico, a natureza inanimada do corpo é deixada de lado e a interaçăo corpo e mente passa a vigorar através dos preceitos nietzschiano, entendendo-se o corpo como estrutura social constituída de muitas almas (CAMPELLO; SCHIMIDT, 2015). O discurso psicanalítico, por intermédio dos estudos de Freud, coloca o corpo sexualizado como resultado da interaçáo entre biologia, instintos e pulsôes da libido e eleva a percepçáo da coexistência natureza e cultura na construçấo corpórea.

Com o conceito de falo, o discurso psicanalista freudiano definiu sua abordagem sexual fora do âmbito biológico, enquanto disparidade entre os sexos, de acordo com a distinçăo entre os órgăos, partindo para uma concepçăo de base natural e cultural, numa interrelaçấo entre corpo e linguagem. Segundo o psicanalista, ambos os sexos passariam por fases idênticas de desenvolvimento da libido - oral, anal e genital - e entâo se diferenciariam na fase autoerótica, na qual o menino passaria pelo complexo de édipo e a menina pelo complexo de Electra (BEAUVOIR, 1949 [2019]).

O discurso feminista do final da década de 50, mais precisamente através das contribuiçôes de Beauvoir (1949 [2019]), critica a definiçấo dada pela teoria freudiana para a libido feminina. Para Freud, ao compreender a diferença anatômica entre os sexos, a menina reage à ausência do pênis pelo complexo de castraçâo, e passa a repelir a pretensâo de virilidade. Nessa esteira, ambos os complexos (castraçâo e Electra) se fortalecem de forma mútua. Ao tentar reagir ao complexo de castraçâo, a menina recusaria sua feminilidade e ambicionaria o falo, para assim identificar-se com o pai. Essa 
renúncia acarretaria a permanência no estágio clitoridiano, podendo causar frigidez ou a homossexualidade.

Beauvoir (1949[2019]) rejeita a sexualidade feminina calcada nesse modelo masculino proposto pelo psicanalista, por restringir a mulher ao status de um "homem mutilado". A autora ressalta que esse ideal de mutilaçăo traz à tona uma comparaçáo e valorizaçấo sobre o falo, que, para o menino, implicaria um sentido de orgulho do órgâo sexual, enquanto, para a menina, seria motivo de inveja (BEAUVOIR, 1949 [2019]). A autora assevera ser essa soberania do falo de ordem social, acarretando impedimentos sociais à mulher. Caso a mulher conseguisse afirmar-se enquanto sujeito, esse privilégio anatômico poderia ser transfigurado do falo para outro objeto, que poderia se tornar ainda mais precioso que o próprio falo. Destaca-se entăo, no discurso psicanalítico, a importância do contexto histórico e social na compreensâo do corpo feminino e masculino e na percepçâo do que se entende por homem e mulher em uma sociedade.

A temática sexualidade como efeito do/sobre o corpo também permeou o discurso filosófico do século XX. O discurso filosófico foucaultiano filia a constituiçấo do corpo ao dispositivo da sexualidade, sendo este concebido como conjunto heterogêneo de práticas discursivas e institucionais sobre o sexo:

\begin{abstract}
A sexualidade é o nome que se pode dar a um dispositivo histórico: nâo à realidade subterrânea que se apreende com dificuldade, mas à grande rede da superfície em que a estimulaçáo dos corpos, a intensificaçăo dos prazeres, a incitaçăo ao discurso, a formaçăo dos conhecimentos, o reforço dos controles e das resistências, encadeiam-se uns aos outros, segundo algumas grandes estratégias de saber e de poder. (FOUCAULT, 1988, p. 100)
\end{abstract}

Nessa perspectiva, o dispositivo da sexualidade elabora um novo efeito sobre o corpo, transportando os sentidos do discurso religioso do sexo como pecado para os sentidos de corpo vivo. O sexo passa a ser visto como responsabilidade biológica, inerente à vida, sendo, portanto, necessária a criaçăo de um dispositivo de controle das práticas sexuais. Esse dispositivo estaria inscrito em um jogo de poder desenvolvido na sociedade disciplinar e seria responsável pela formaçăo das relaçóes sociais e pela regulaçăo dos corpos.

Amparada na vigilância e no controle, essa sociedade disciplinar constrói o discurso do/sobre o corpo por meio da manipulaçâo e do treinamento, a fim de torná-lo um corpo dócil (FOUCAULT, 1987). Esse corpo submisso às técnicas de produçâo e dominado pela disciplina é configurado a partir dos ideais de utilizaçăo, transformaçâo e aperfeiçoamento e quanto mais útil, mais dominado seria. O corpo estaria no âmbito da objetificaçăo, como um produto moldado para um fim específico. Esse dispositivo disciplinar está na base da representaçáo da sociedade de Gilead no Conto da Aia, em que as mulheres săo classificadas segundo o treinamento de seus corpos como objetos a serem dominados e utilizados, e pela sua utilizaçăo tornarem-se submissos.

Nas relaçôes de saber e poder que engendram o dispositivo da sexualidade, a repressâo expressa sua relaçâo com a burguesia. Para Foucault (1988), foi ela a responsável pela conceituaçấo de sexualidade sadia e do corpo săo, negando ao proletariado o reconhecimento de seu corpo e de sua sexualidade. Segundo o filósofo, a partir do século XIX, por meio do controle judiciário e médico das perversóes, o dispositivo da 
sexualidade, elaborados primeiramente pela e para as classes mais privilegiadas, passa a se difundir em todas as camadas sociais.

Baseado nessa difusâo do dispositivo, o sexo se torna uma forma de regulaçấo sobre o corpo e o comportamento da populaçâo, já que ele náo age sobre as duas camadas, burguesa e proletária, da mesma maneira, nem possui o mesmo efeito. Nesse dispositivo, a classe proletária năo se percebe representada quanto ao seu corpo e a sua sexualidade. Os aparelhos administrativos e técnicos que implementaram esse dispositivo, estabelecia a burguesia como base de parâmetro social hegemônica, excluindo a classe trabalhadora.

Os discursos reguladores da normatividade instituem, entăo, modelos de corpos que devem ser disciplinados e controlados, como a mulher, o homossexual, a criança entre outros. Ainda seguindo o raciocínio foucaultiano, o poder e o saber sobre o sexo se articulam no discurso, veiculando e produzindo sentidos sobre ele. As práticas discursivas criam dessa forma o imaginário sobre os sujeitos, separando-os entre aqueles pertencentes à classe hegemônica, tidos como normais, e aqueles tidos pela anormalidade, como a mulher histérica, o pervertido, a mâe homicida, o marido sádico, etc.

Por intermédio dessas práticas discursivas, a sexualidade até o século XVIII era vista sob a ótica masculina. A sexualidade feminina ganha destaque com a discussăo acerca dos problemas correlatos da maternidade, do aleitamento e seus derivados. No século XIX, a masturbaçăo feminina toma certa relevância diante outras questōes relacionadas ao sexo da mulher e torna-se algo dramático a ser analisado no nível médico-social (FOUCAULT, 1979). O processo de histerizaçăo do corpo da mulher também está alicerçada nesse nível: o corpo ao ser analisado como saturado pela sexualidade e sob o efeito de uma patologia inerente inaugura o imaginário da "mulher nervosa". A sexualidade feminina passa a ocupar o imaginário da anormalidade, conferindo-se a ela uma patologia intrínseca e que deveria ser controlada.

Alicerçada nas teorias foucaultianas, Butler (1999) acrescenta à rede de memória do/sobre o corpo a perspectiva da performatividade, desestruturando o ideal de sexo biológico e de construçâo de gênero como produtos da natureza e interrelacionados à heterossexualidade. Para a filósofa, "as normas regulatórias do sexo trabalham de uma forma performativa para construir a materialidade dos corpos, e mais especificamente, para materializar o sexo do corpo" (BUTLER, 1999, p. 154).

O conceito de performativo compreende, assim, o corpo e o gênero como práticas discursivas e rejeita o imperativo heterossexual, que classifica os corpos por meio de dicotomias do tipo feminino e masculino, submisso e emancipado, anormal e normal, pervertido e íntegro. Dessa forma, para Butler, os atributos de gênero săo os diversos modos utilizadas pelos corpos para produçâo de significados culturais, năo sendo, portanto, preexistentes, impossibilitando classificaçôes como verdadeiro ou falso, real ou distorcido ou, ainda no dizer da autora, qualquer "ficçăo reguladora" (BUTLER, 2016, p. 244). O corpo pensado no performativo deixa de ser visto pelas amarras da dominaçăo masculina e da heterossexualidade compulsória, como vinha sendo pensado e imposto até entăo.

Ainda faz parte dessa rede de memória sobre o corpo o discurso feminista pós-década de 1970. Ao colocar o corpo feminino como centro de disputas entre o público e o privado, o movimento rompe com os sentidos produzidos pelos discursos filosóficos, 
religiosos e científicos que colocavam o corpo e a sexualidade do sujeito mulher sob a ótica masculina. Inicia-se o processo de formulaçáo de teorias críticas aos mecanismos de controle sobre o corpo e a sexualidade feminina que dariam sustentaçáo à teoria e à prática feminista contemporânea (SCAVONE, 2010). Visando a liberdade e a autodeterminaçăo dos corpos femininos, o movimento reivindica a desconstruçăo do discurso dominante que encerra o corpo do sujeito mulher sob a ótica da sexualidade reprodutiva, tendo como meta a separaçăo da sexualidade e da procriaçăo:

Para o feminismo, tal separaçáo descontruía o naturalismo da reproduçáo com o sexo biológico, portanto, o movimento buscava garantir a liberdade de escolha do uso da contracepçâo, assim como seu direito para todas as mulheres. Ao mesmo tempo, questionava a ausência de pesquisas para a contracepçăo masculina, pois se tratava, também, de incluir os homens na reproduçăo (SCAVONE, 2010, p. 50).

Essa separaçăo subverteria o lugar atribuído às mulheres pela ideologia patriarcal no espaço público e privado. A máxima "Nosso corpo nos pertence" torna-se lema desse período, pondo em destaque a discussâo acerca do destino biológico imposto às mulheres, questionando seu lugar social para além da maternidade compulsória e o domínio sobre seu corpo.

Contudo, a separaçăo entre sexualidade e reproduçăo só foi possível através das tecnologias masculinas de poder, como nos fala Scavone (2010), pela criaçăo, na década de 60, e ascensăo, a partir da década de 70, de métodos contraceptivos, como a pílula contraceptiva e o DIU. A autora lembra que essas tecnologias contribuíram para a manutençâo do que a autora chama de "determinismo biológico procriativo feminino" (2010, p. 51), uma vez que a medicina marginalizou as pesquisas de divulgaçăo e utilizaçăo de métodos contraceptivos masculinos, mantendo sob a mulher a responsabilidade da contracepçáo.

Ainda nesse viés, o movimento feminista inclui em seu discurso sobre o corpo a luta pela legalizaçăo do aborto, entendo-o como um "problema das relaçôes de poder entre homens e mulheres" (SCAVONE, 2010, p. 54), já que expressa a violência sobre a vulnerabilidade dos corpos femininos diante de uma gravidez indesejada. A luta pelo direito ao aborto permanece no discurso feminista, ganhando, a partir dos anos 1980 em diante, uma abordagem acerca dos direitos sexuais e reprodutivos, considerando de forma mais ampla as questôes concernentes a sexualidade e reproduçăo.

A rede de memória pontuada até aqui nos mostra o regime de dominaçăo exercido sobre os sentidos do/sobre corpo em diversos momentos históricos através de diferentes discursos. O discurso filosófico da antiguidade grega, o cristâo medieval e o científico renascentista representam o efeito de controle determinado sobre o corpo, tanto masculino quanto feminino, principalmente em relaçăo ao último. $\mathrm{O}$ corpo é discursivizado enquanto materialidade que se contrapóe a uma subjetividade que deve ser preservada. A sexualidade é dominada e determinada por regras morais. O prazer e o desejo configuram-se como pecaminosos ou irrelevantes para o sujeito. A mulher é caracterizada pela sua diferença e desigualdade em relaçâo ao homem, sendo sempre o outro negativo ou subordinado do sexo masculino.

No entanto, notamos, em determinados momentos, a emergência de discursos que questionam esses sentidos estabilizados para o corpo, produzindo um efeito de resistência aos processos de dominaçăo. Através dos discursos filosófico do século 
XIX, do psicanalítico freudiano, do filosófico foucaultiano, da performatividade e do feminista, percebemos um movimento de deslocamento dos sentidos atribuídos para o corpo e para a sexualidade feminina. O corpo deixa de ser significado pela dualidade entre o material e espiritual, configurando como um todo complexo, social e histórico, e passível de diversas análises.

Nesse percurso, percebemos como o corpo é atravessado e afetado pela história, pela memória, pela ideologia e pela cultura. Nessa perspectiva, enquanto falha, dispersâo, torçâo (FERREIRA, 2013), o corpo é lugar de dominaçâo e de resistência, alienaçăo e lucidez, funcionando como lugar de materializaçâo de aspectos políticos que o constituem e o refletem nos discursos. Nas obras analisadas nesse trabalho, percebemos como essa rede de memória produz efeitos sobre os modos de discursivizaçăo do corpo do sujeito mulher Aia, tanto pelo funcionamento da dominaçăo quanto pelo da resistência, mobilizando ou nâo o erótico, que se instaura nas falhas e equívocos da ideologia e da língua.

\section{QUE (NÃO) PODE UM CORPO? GESTOS DE ANÁLISE}

Ao pontuarmos a rede de memória que produz e é produzida pelo corpo, procuramos evidenciar alguns dos sentidos que atravessam o imaginário social e ressoam nos discursos ao longo da história. A construçâo discursiva do corpo do sujeito mulher nas obras de Atwood e Miller é perpassada por dois funcionamentos discursivos, seja pelo viés da interpelaçăo ideológica religiosa, seja do rompimento com esta filiaçăo através da mobilizaçăo de sentidos de resistência. Esses funcionamentos, porém, materializados no discurso sobre mulher, corpo e poder, năo se dăo de forma pura, plena, mas num tensionamento entre efeitos de dominaçăo e de resistência.

Em ambas as obras, temos um contexto político e social distópico de um regime autoritário e teocrático inspirado na interpretaçâo de essência patriarcalista do primeiro testamento da Bíblia. Na sociedade Gilead, as mulheres săo submissas aos homens e destituídas de seus nomes, referidas pelas suas funçôes sociais, que se restringem ao ambiente doméstico ou sexual.

Os acontecimentos, nas versōes literária e fílmica de 0 conto da Aia, sâo narrados pela personagem Offred ("de Fred"), aia designada para a família do Comandante Fred. O grupo das Aias é composto por mulheres que năo possuem prestigioso social e religioso, mas têm capacidades reprodutivas preservadas, depois do acidente ambiental retratado pela autora. $O$ enredo se desenvolve a partir da chegada de Offred à casa do seu novo Comandante, narrando todo o processo de convivência entre a Aia, Fred e sua Esposa, Serena Joy.

Durante sua estadia nas casas dos comandantes, as Aias săo obrigadas a participar da Cerimônia, ritual para reproduçáo baseado em um trecho bíblico em que săo expostas as condiçôes para as relaçôes sexuais entre Comandante e Aia. Nessas cerimônias, as Esposas seguram suas Aias pelos punhos, enquanto estas estăo deitadas e săo penetradas pelos comandantes, que náo devem tocá-las em nenhum outro momento ou parte do corpo que náo seja para esse fim, já que o ato sexual deve ser cumprido apenas como reproduçấo e năo como expressâo do desejo corporal. 
Os discursos literário e fílmico abordam a violência sofrida pela Aia nessas práticas de modos singulares, que veremos mais adiante, contudo nas duas linguagens há certa tensăo entre as posiçōes sujeito dominado e resistente em que a aia é colocada.

A representaçăo do corpo, em ambas as obras, se caracteriza por um funcionamento discursivo demarcado por dois efeitos de sentido : o do corpo reprodutor, representando o assujeitamento à ideologia religiosa e patriarcal dominante em Gilead e que convoca as mulheres à assunçâo de um corpo disciplinado; e o do corpo resistente, que remete a um efeito da contradiçáo dentro da FD religiosa, dando margem a duas posiçóes possíveis: a posiçāo corpo-subsistência, segundo a qual o corpo é visto como objeto de troca e manutençâo da lucidez do sujeito mulher ao regime autoritário; e a posiçâo corpo erótico, pela qual há um rompimento com a FD religiosa através da expressâo do desejo erótico feminino.

Acreditamos que os funcionamentos discursivos acerca do corpo dominado e resistente nas duas materialidades significantes sob análise sáo similares, pois ambos problematizam os sentidos atribuídos para a dominaçáo e a resistência no/do corpo. Contudo, o discurso fílmico desloca alguns desses sentidos, produzindo um funcionamento diferente do literário. Desse modo, questóes como a retomada do nome verdadeiro de Offred, a denominaçâo da Cerimônia como estupro pela personagem e o modo de visualizaçâo do corpo erótico exposto na série săo formas de atualizaçăo do texto literário que produzem sentidos outros quanto à questâo da resistência. Para os sentidos da dominaçăo, iremos ver que nos dois discursos os efeitos de sentido săo similares.

\subsection{Bendito Seja o Fruto: Sentidos para o Corpo Dominado}

O primeiro efeito que iremos explorar no discurso literário e fílmico de 0 conto da Aia é caracterizada pela representaçấo do corpo assujeitado à ideologia religiosa. Pelo funcionamento da memória (PÊCHEUX, [1983]2014), os sentidos do corpo feminino da ideologia judaico-cristă que o vincula à funçăo biológica de reproduçáo e à manutençấo da família sâo retomados, colocando a sexualidade feminina como transgressăo à lei, divina e terrena. É o que podemos constatar na SD 1, uma fala de Offred.

SD1: Somos úteros de duas pernas, apenas isso: receptáculos sagrados, cálices ambulantes (ATWOOD, 2017, p. 165).

Na SD1, o corpo é metaforizado como "úteros de duas pernas", "receptáculos sagrados" e "cálices ambulantes". O uso de termos como "receptáculos sagrados", "cálices ambulantes" faz remissâo a sentidos religiosos (sagrado e cálice), associados a objetos de uso pelos poderosos e religiosos (receptáculos, cálices). Essas metáforas materializam processos de objetificaçăo do corpo da mulher em nome da religiăo e ainda realçam o menosprezo e abandono da mulher nesse contexto. Os sentidos da dominaçăo estăo presentes no uso do termo "somos", uma vez que o sujeito se inclui nessa representaçăo do corpo feminino, mas ao evidenciar "apenas isto" percebemos um tensionamento na representaçâo dominante, quando afirma ser isso o mínimo possível, fazendo ressoar um Outro impossível.

O efeito de objetificaçâo do corpo do sujeito mulher é ressaltado durante a apresentaçâo da Cerimônia em que Aia é obrigada a manter relaçâo sexual com o Comandante enquanto é segurada por sua Esposa. Nesse momento, a personagem evidencia sua falta de sentimentos ante a situaçăo em que é submetida. 
SD 2: [...] nâo tem nada a ver com paixăo ou amor, ou romance ou qualquer daquelas outras noçôes com as quais costumávamos nos empolgar. Nâo tem nada a ver com desejo sexual, pelo menos nâo para mim, e certamente nâo para Serena. Excitaçăo sexual e orgasmo năo săo mais considerados necessários; seriam meramente um sintoma de frivolidade, como ligas rendadas ou pintas falsas: distraçóes supérfluas para os volúveis." (ATWOOD, 2017, p. 114 e 115).

Na SD2, temos um confronto entre duas posiçóes colocadas em jogo através da negaçăo polêmica (INDURSKY, 1990). Este tipo de negaçáo expressa, simultaneamente, no mesmo enunciado, dois pontos de vista antagônicos de dois enunciadores, um enunciado positivo de um enunciador anterior e o negativo do segundo enunciador, com o qual o locutor se identifica. Na SD2, notamos, assim, dois pontos de vista antagônicos: para o primeiro, o ato sexual é produto da "paixâo" e do "amor", "do desejo sexual", da "excitaçấo" e do "orgasmo"; para o segundo, nada disso é mais importante, săo "frivolidades" "distraçōes supérfluas" e "para os volúveis". O sujeito autor apresenta o personagem como um sujeito dividido em posiçôes antagônicas ao mobilizar as duas perspectivas.

Ainda na SD2, percebemos que o discurso da personagem expóe o processo de dominaçăo dos corpos, ao demonstrar o que antes era importante no envolvimento sexual (excitaçăo sexual e orgasmo), mas que năo é mais possível, significando-o segundo a ótica do discurso dominante (frivolidade e distraçôes). No entanto, o discurso dominante é tensionado ao serem mencionados na fala da personagem sentidos interditados ao sujeito, como "paixăo", "desejo sexual", "excitaçấo" "orgasmo", trazendo à superfície do texto a falha ideológica, a resistência, percebida pela impossibilidade de proibir a emergência desses sentidos.

Ainda na SD2, o sujeito autor evoca o corpo do sujeito mulher através da representaçấo do ato sexual, retomando pela memória discursiva os sentidos do distanciamento emocional e erótico evidenciados pelo imaginário religioso. As formulaçôes destacadas se inscrevem na rede de sentidos do discurso cristăo medieval sobre o corpo (FEDERICI, 2017), definido pela divisăo entre o que era permitido ou interditado no ato sexual, o que era ou nâo pecaminoso perante o julgamento da Igreja.

Os sentidos do sexo exclusivo para reproduçáo e o desejo sexual como pecado sáo assim retomados sempre que o corpo é representado nos rituais de Cerimônia ou até mesmo nos rituais de Salvamento, em que alguma aia ou esposa tenha se deixado levar pelo pecado da carne, fugindo do seu destino bíblico.

No discurso fílmico, o efeito de inércia é produzido pela linguagem corporal durante o ritual, produzindo sentidos para a dominaçáo por meio do controle sobre o corpo do sujeito mulher. A falta de contato além do necessário para a reproduçâo, a posiçâo dos corpos feita de forma extremamente controlada e a indiferença demonstrada pelo olhar vago e distante da Aia, produzem o efeito de insensibilidade e submissáo às regras de conduta que devem ser seguidas, como aquelas afirmadas no discurso religioso representado pela história bíblica de Raquel e Lea e que é sempre retomado na obra.

A cena se torna mais escura. O plano médio da cena, ao destacar o posicionamento dos personagens de forma mais aproximada, mostra como cada movimento é calculado no sistema patriarcal e religioso representado na obra, significando a submissâo da mulher e o controle sobre seu corpo. 


\section{SD 3: 0 corpo dominado no discurso fílmico}

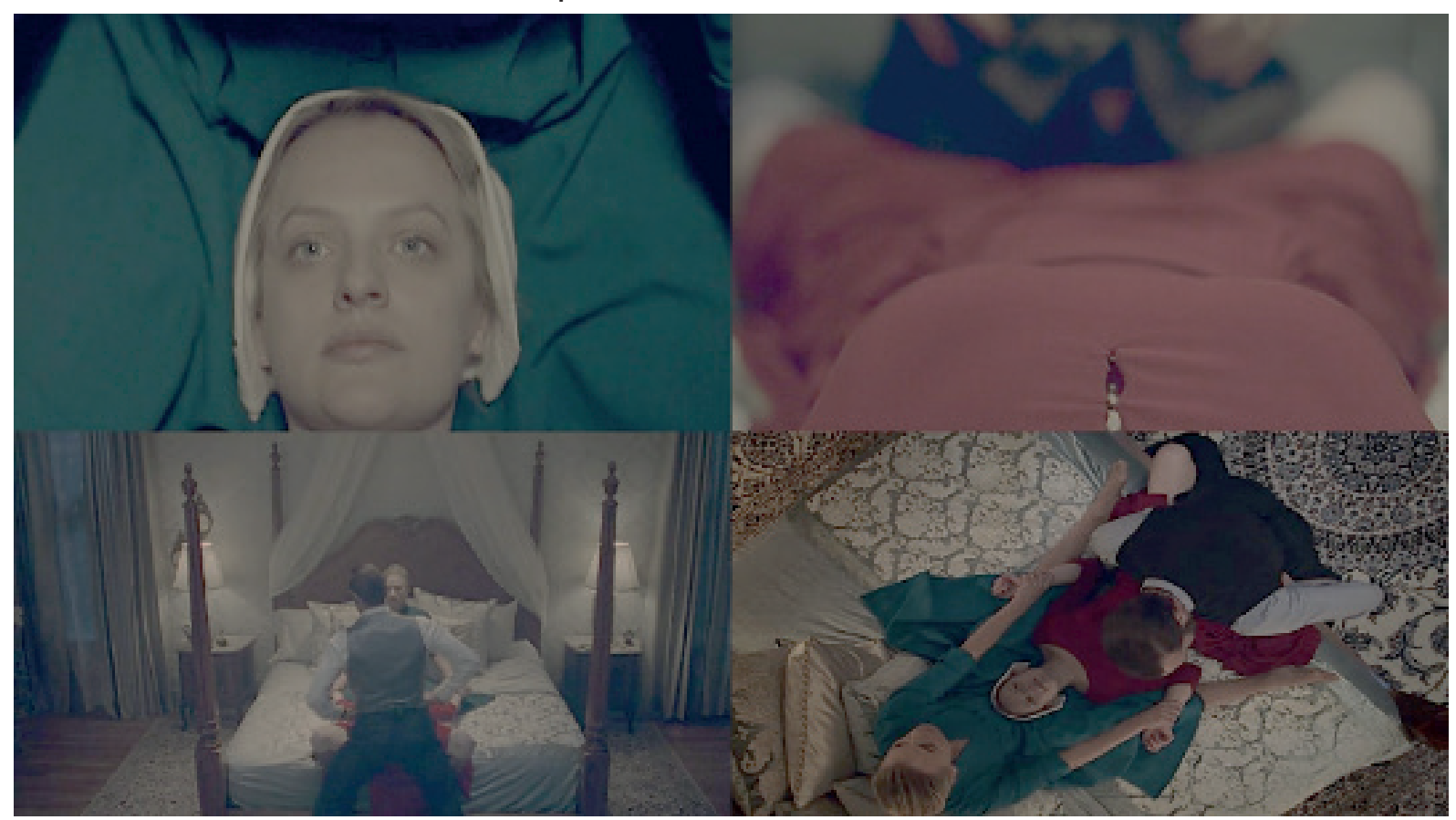

Fonte: THE HANDMAID'S..., $1^{\mathrm{a}}$ temporada, cenas do episódio 1 (HULU, 2017).

O efeito de controle sobre o corpo demonstra o assujeitamento à ideologia religiosa, através das mâos da aia seguradas pela esposa, caracterizando a posiçấo assumida pelo corpo dominado um elemento em relaçấo de paráfrase com o dito popular "de mâos atadas", já que o destino de aia é a reproduçâo compulsória. Temos ainda, o efeito de controle evidenciado na representaçăo do corpo como um receptáculo que está disponível apenas para reproduçăo humana e controlado para esse fim. Nas cenas que compóem a SD3, o ambiente se torna mais escuro, as cores das roupas dos personagens trazem o efeito de contraste demarcando os papéis assumidos na sociedade, e consequentemente na noite de cerimônia. A nomeaçăo como "cerimônia" produz o efeito de sacralidade, atenuando assim a violência sofrida pelo sujeito mulher. Evidencia também uma crítica ao imaginário religioso sobre o corpo feminino, por se utilizar dos sentidos da religiâo (cerimônia) para justificar o ato violento.

Se retomamos Foucault (1987) e sua teorizaçâo sobre o corpo dócil/disciplinado pela sociedade disciplinar, caracterizada pela vigilância e controle, notamos que o corpo do sujeito mulher representado na obra literária nos remete a ideia de manipulaçăo e treinamento, já que a mulher anterior a classe das aias năo seria obrigada a tal situaçăo. No livro, o sujeito-autor inscreve a personagem na posiçâo de submissâo ao sistema, ao defender năo ser estupro o ritual de Cerimônia a qual ela é obrigada, uma vez que ela tinha o poder de escolher entre ser uma Aia ou morrer, na colônia ou na forca.

Desse modo, o discurso sobre o sujeito mulher e seu corpo, evidenciados na obra literária, demonstra como os processos de dominaçăo se dāo através de práticas discursivas que colocam em jogo o efeito de evidência produzido pela falsa possibilidade de escolha do sujeito para assumir uma posiçăo, entre outras possíveis, mesmo que essas outras posiçóes sejam extremamente restritivas. 
Ao contrário do livro, no discurso fílmico, em uma de suas cenas (episódio 6, temporada 1), Offred, em uma discussâo com o motorista Nick, nomeia o ato sexual da Cerimônia como estupro, como podemos ver na transcriçăo das falas do episódio:

SD 4: - Foda-se Nick, foda-se. Eles náo te estupram, năo é? Eles náo vêm aqui uma vez por mês ler a Bíblia e enfiar o pau em você.

- Offred.

- Năo me chame assim! Năo é o meu nome. Meu nome é June (THE HANDMAID'S..., 2017, $1^{\text {a }}$ temporada).

Ao trocar os termos, a série rompe com a representaçăo da personagem assujeitada a esse corpo dominado e mobiliza os sentidos para um discurso de resistência, em que se revela a ruptura do ritual ideológico de percepçăo desse corpo objetificado pelo religioso. Segundo Pêcheux (1982[1990, p. 17]), "mudar, desviar, alterar o sentido das palavras e das frases" se constitui como pontos de resistência possibilitadas dentro de um ritual ideológico. Dessa forma, deslocam-se os sentidos reproduzidos pelo discurso de dominaçāo.

O discurso de resistência de/sobre o corpo se constitui sob o modo de nomear aquilo que o subjuga e violenta. Dessa forma, percebemos que, conforme o autor, a resistência parte do interior da ideologia dominante, possibilitando ao sujeito sustar aquilo "que reproduz o discurso da dominaçăo, de modo que o irrealizado advenha formando sentido do interior do sem-sentido" (PÊCHEUX, 1982 [1990, p. 17]). Ao mudar a denominaçăo de Cerimônia para estupro, o sujeito autor questiona o discurso dominante, pondo em relevo a violência sofrida pelo corpo. Isto evidencia o apagamento que o discurso religioso produz ao colocar o ato como um ritual religioso.

Ainda sob a orientaçăo de Pêcheux (1982[1990]), nossa análise seguirá para a compreensâo de outros efeitos produzidos sobre a ideologia dominante que representam uma forma de resistência nas obras literária e fílmica de 0 conto da aia. Dessa forma, analisaremos o corpo enquanto um dispositivo de visualizaçăo que produz efeitos de resistência ao possibilitar ao sujeito dispor de seu corpo, seja pela sobrevivência ao regime autoritário, seja para assunçăo do desejo erótico.

\subsection{Nolite te Bastardes Carborundorum: Sentidos para o Corpo Resistente}

Outro modo de materializaçáo discursiva do corpo feminino em $O$ conto da aia se dá através da falha, do rompimento com o discurso de dominaçăo, ou seja, pela produçâo de efeitos de deslocamento do sentido do corpo dominado para um ideal de corpo performativo, expressăo de suas vontades. O corpo resistente é caracterizado pela contradiçâo instaurada no interior da representaçăo ideológica religiosa e se dá através de duas posiçóes assumidas no interior discurso literário e fílmico: a posiçâo corpo-subsistência e a posiçâo corpo-erótico. Em ambas, a construçăo do discurso de resistência coloca em jogo a contraidentificaçāo ou desidentificaçăo (PÊCHEUX, [1975] 2014) com a ideologia religiosa que é representada nas obras analisadas. O que diferencia as duas posiçôes é a assunçâo do erótico enquanto efeito basilar. Na primeira posiçâo, o funcionamento discursivo de resistência materializa o corpo como objeto de troca e manutençăo da lucidez do sujeito mulher no regime autoritário; na segunda, temos o rompimento com o imaginário religioso pela explicitaçáo do desejo erótico feminino. 
Nas duas obras analisadas encontramos materialidades representativas de ambas as posiçóes possíveis para o corpo resistente. A SD 5 é um recorte de uma situaçâo discursiva da materialidade literária na qual a personagem Offred relata um encontro proibido com o comandante Fred, realizado contra sua vontade, como forma de manter-se viva, uma vez que, contrariado, o comandante poderia denunciá-la por algum crime inventado como vingança.

SD 5: Ele abaixa uma de minhas alças, desliza a outra máo para dentro em meio às pernas, mas náo adianta, fico deitada ali como um pássaro morto. Ele !!!náo é um monstro, penso. Náo posso me dar ao luxo de ter orgulho ou aversáo, há todo tipo de coisas que tem de ser descartadas diante das circunstâncias. [...] Sem seu uniforme ele parece menor, mais velho, como algo ficando seco. $O$ problema é que năo posso ser, com ele, em nada diferente da maneira como habitualmente sou com ele. Habitualmente sou inerte. Com certeza deve haver alguma coisa aqui para nós, além dessa futilidade digna de pena. [...] Finja, berro para mim mesma dentro de minha cabeça. Você deve se lembrar como. Vamos acabar logo com isso, senăo você ficará aqui a noite inteira. Movimente-se. Mexa esta sua carne um pouco, respire de maneira audível. É o mínimo que você pode fazer. (ATWOOD, 2017, pp. 302 - 303)

A SD 5 mobiliza sentidos do erótico (desliza a outra măo para dentro em meio às pernas) para distinguir as açóes da noite de Cerimônia e o encontro furtivo entre os personagens. Ao trazer a negaçăo, (mas năo adianta, fico ali deitada como pássaro morto), a falta de desejo e excitaçăo na qual se encontra o sujeito é indicada e se contrapóe ao erótico evidenciado como sentimento do outro. A vontade do sujeito năo perpassa pelo desejo erótico de transcendência do ser, como defende Bataille (1987), pois o sujeito nâo se apropria do corpo para projeçăo do seu gozo, mas apenas para o de outrem, năo transbordando a barreira do sexo e tensionando no interior dessa materialidade sentidos da dominaçăo, ao nâo possibilitar a negativa por parte da aia como uma posiçâo legitimada.

O funcionamento discursivo da resistência sobressai quando a personagem Offred assume o encontro com o Comandante como algo a que náo se submeteria em outra realidade ("há todo tipo de coisas que tem de ser descartadas diante das circunstâncias"). Com isso, deslizamos sentidos do ato sexual enquanto reproduçáo para os de troca, negociaçăo, subvertendo a ordem vigente e expondo outra posiçăo além da obediência ao regime.

O efeito de fingimento produzido ("Finja, berro para mim mesma dentro de minha cabeça. Você deve se lembrar como") joga com as possibilidades para resistir à dominaçăo, ao colocar o sujeito em outra posiçấo, subvertendo a obediência devida pela classe das Aias, e expondo sua vontade de demonstrar algum sentimento, seja no intuito de agradar ou de deixar aberto para novas oportunidades. Nesse viés, o corpo se coloca no espaço da falha, como resistência à simbolizaçâo da forma dominante, abrindo-se a possibilidades outras, nâo previstas pela formaçâo ideológica patriarcal e religiosa.

Como podemos ver, o ato sexual náo seria fruto de um desejo erótico para o sujeito personagem Offred, uma vez que os sentidos sâo materializados pela ideia da mortificaçâo, "um pássaro morto", da "inércia habitual" e do fingimento. A resistência a FD patriarcal e teocrática se dá pela possibilidade que se abre para o uso do corpo para um fim contrário ao proposto pelo imaginário social dominante do contexto descrito no texto literário. Mesmo náo rompendo de forma total com a FD que esse imaginário 
representa, uma vez que o corpo ainda está no plano da objetificaçăo. Os sentidos produzidos na mobilizaçăo dos sentimentos da personagem mostram o processo discursivo de resistência como modo de sobreviver ao destino de aia.

A inércia como efeito de controle sobre o corpo do sujeito mulher é retratada também na SD 6, representando o encontro entre Comandante e Aia ao mostrar a impossibilidade de o sujeito dizer năo. Para a personagem, a finalidade do encontro é a execuçấo de um plano importante para o movimento de resistência abordado na obra, - Mayday, que luta contra o regime autoritário em Gilead. Para o sujeito comandante o que conta é a realizaçăo do seu desejo. Já para a personagem Aia, a projeçăo do gozo como expressâo do desejo de transcendência náo está presente na forma como o corpo se expóe ao olhar do outro na SD6, como podemos ver.

\section{SD 6: 0 corpo resistente - posição corpo-subsistência}

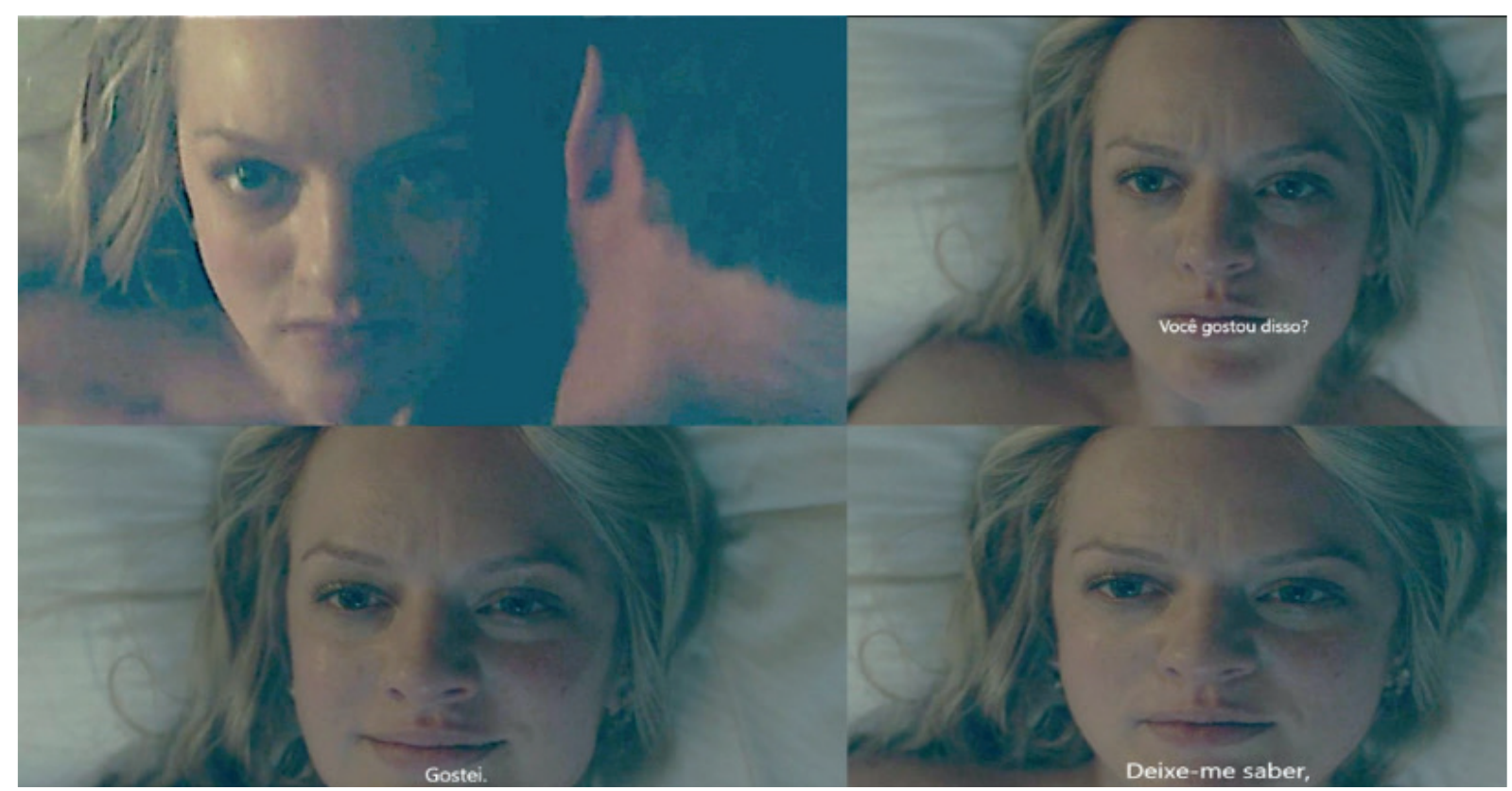

No processo discursivo evidenciado no quadro ??abaixo, a resistência é produzida pelo modo como o discurso fílmico e sua materialidade significante representa a personagem. Na primeira cena da SD6, é perceptível no rosto da personagem a expressâo de raiva, vingança, desprezo. Sendo o corpo um dispositivo que se expóe ao olhar, como nos fala Ferreira (2013), ele materializa os sentimentos do sujeito, exteriorizando-os e tornando-os perceptíveis e passíveis de gestos de interpretaçăo. Ao ser questionada se gostou do que aconteceu, o corpo da personagem é representado por meio de três expressóes diferentes: uma logo após o ato, expressando tristeza; a segunda, ao falar que gostou, evidenciando um riso forçado, produzindo sentidos de satisfaçăo; e o último, com um olhar mais longe, ressoando sentidos de esperança em saber que poderá usar desse artificio outra vez.

O discurso de resistência na SD 6 funciona a partir da utilizaçăo do corpo como objeto de dissimulaçấo da sua intençấo, como artifício para conseguir algo que lhe é 
importante. O processo de dominaçâo é materializado a partir da representaçăo da impossibilidade de recusa sobre o convite, mas que possui falhas ao permitir que a vontade do sujeito se sobreponha a açâo dominante, produzindo sentidos de resistência. O discurso fílmico evidencia como as relaçóes de poder exercidas por um regime autoritário na interdiçâo do corpo abre espaço para a transgressăo da personagem aia ao assumir outra posiçăo diante daquelas que lhe săo impostas, nesse caso no uso do sexo como dissimulaçấo da intençâo do sujeito, desvinculado do ideal reprodutivo.

Enquanto no discurso literário a troca de favores entre Comande e Aia se dá por motivo individual, para sobrevivência e manutençâo do ser, no discurso fílmico ela tem motivaçăo coletiva, como condiçăo para prosseguimento do movimento de resistência, Mayday. Em ambos, o funcionamento discursivo da resistência se materializa na possibilidade de transgressăo do corpo dominado para um corpo de vontades outras, de sentidos outros, convocando o sujeito à assunçăo desse corpo como objeto de uso para sobrevivência.

A segunda posiçâo que o corpo resistente assume no discurso literário e fílmico é a do corpo-erótico. A memória discursiva mobilizada nas obras filia o corpo ao discurso religioso judaico-cristâo da idade média europeia. Nessa rede de sentidos, o corpo é visto como propenso ao pecado, devendo obedecer aos preceitos religiosos como meio de salvaçăo da alma. Como vimos, no percurso da memória sobre o corpo, esse discurso religioso impóe ainda como deve ser o ato sexual para que esse náo seja impróprio. 0 desejo e a excitaçăo náo fazem parte do ritual de reproduçăo, por isso săo discursivizados como desnecessários, como pecado. Percebemos esses sentidos sendo produzidos nas textualidades sob análise nos trechos destacados pelas SD 1, 2 e 3. Para entendermos como o efeito erótico constitui uma nova posiçăo-sujeito para o corpo resistente é importante ressaltamos a diferença entre sexo e erotismo elaborados por Bataille (1987). O autor afirma que

A atividade sexual de reproduçăo é comum aos animais sexuados e aos homens, mas, aparentemente, só os homens fizeram de sua atividade sexual uma atividade erótica, e o que diferencia o erotismo da atividade sexual simples é uma procura psicológica independente do fim natural encontrado na reproduçăo e na preocupaçăo das crianças. Abandonando essa definiçăo elementar, voltarei imediatamente à fórmula que propus inicialmente, segundo a qual o erotismo é a aprovaçăo da vida até na morte. Com efeito, se bem que a atividade erótica seja inicialmente uma exuberância da vida, o objeto dessa procura psicológica, independente, como eu o disse, da preocupaçáo de reproduçáo da vida, năo é estranho à morte. (BATAILLE, 1987, p. 10)

Conforme Bataille, sexo e erotismo se diferenciam por sua finalidade. A atividade sexual enquanto reproduçăo e a atividade erótica enquanto sentimento independente daquele da reproduçâo. O autor coloca o erotismo em um processo parafrástico com a morte, ao dizer que aquele náo é estranho a este, pois uma vez que somos seres descontínuos, distintos uns dos outros, a morte seria responsável pelo fim dessa descontinuidade. Dessa forma, o sujeito ao expressar o erotismo traz à tona o processo de continuidade, conectando-se com o seu interior e com o outro, numa relaçấo entre seres distintos buscando em si o prazer. 
A posiçâo corpo erótico é constituída nesse viés, por meio da relaçăo sujeito-corpo-sujeito, expondo as sensaçóes experimentadas pelo sujeito na busca pelo prazer, SD7, e na sua relaçăo com o outro, SD 8.

SD 7: [...] posso acariciar a mim mesma, debaixo dos lençóis brancos e secos, na escuridăo [...] (ATWOOD, 2017, p. 126);

SD 8: [...] amor, faz tanto tempo, estou viva em minha pele, mais uma vez, envolvendo-o em meus braços, caindo e água a cair suave por toda parte, parece que para nunca se acabar (ATWOOD, 2017, p. 309).

Na SD7, os sentidos do erótico se mostram na relaçăo sujeito personagem com seu corpo no momento da solidáo em seu quarto. O efeito produzido pela ideia do acariciar-se mobiliza os sentidos da masturbaçăo enquanto ferramenta de transgressáo do corpo em uma realidade de dominaçấo. A resistência se materializa pela expressâo desse desejo proibido e pela impossibilidade do poder dominante de apagar essa necessidade do sujeito e seu instinto.

O texto materializa a impraticabilidade da submissăo completa do sujeito dominado, demonstrando tensionamentos possíveis na formaçăo discursiva religiosa e patriarcal. No relato do autoacariciamento, os sentidos produzidos para o corpo ultrapassam os impostos pela ideologia dominante representada no discurso literário, pois constitui para o sujeito um lugar de autonomia sobre o próprio corpo. O desejo perpassa a individualidade, e o resistir está em desafiar, mesmo que de forma escondida, o que o discurso dominante năo permite, ou seja, na falha, como nos diz Orlandi (2016), na abertura permitida pelos momentos de solidăo.

Na série, esse momento năo é destacado na primeira temporada, objeto de nossa análise. O corpo-erótico se desvela na relaçáo entre o corpo do sujeito mulher e outro corpo. Nela, o discurso erótico remete a sentidos de consensualidade, a satisfaçăo, desejo e segurança.

SD 9: Estar aqui com ele é segurança; é caverna, onde nos aconchegamos juntos enquanto a tempestade continua lá fora. É uma ilusăo, é claro. O quarto dele é um dos lugares mais perigosos em que eu poderia estar. Se fosse apanhada náo haveria quartel. Mas está além de minhas forças me importar. (ATWOOD, 2017, p. 318)

Esses sentidos convergem para o desejo de transgressâo do ser, que encontra no ato sexual o erótico, assumindo o risco, mas abrindo-se para o sentimento de prazer. 0 discurso erótico póe em evidência sentidos para resistência ao se constituir enquanto posiçấo contrária à censura estabelecida ao corpo pela ideologia dominante. O efeito erótico apaga a inércia do corpo e o coloca como possuidor de vontades, capaz de desafiar o sistema, metaforizado como "tempestade", mesmo colocando em risco sua vida ("Se fosse apanhada năo haveria quartel"). O erotismo, diz Bataille, surge do jogo entre o interdito e a transgressáo, colocando os sujeitos, homens e mulheres, em um "movimento do ser em nós mesmos" (BATAILLE, 1987, p. 28). É o que se mostra nas formulaçóes das SDs que apresentamos, que evocam o movimento do ser pelo desejo.

Na série, a posiçâo corpo-erótico integra sentidos que afrontam os interditos sobre a nudez, o cabelo, o contato entre corpos e a excitaçăo sexual, como podemos ver na SD 10. 
SD 10: Corpo resistente - posição corpo-erótico

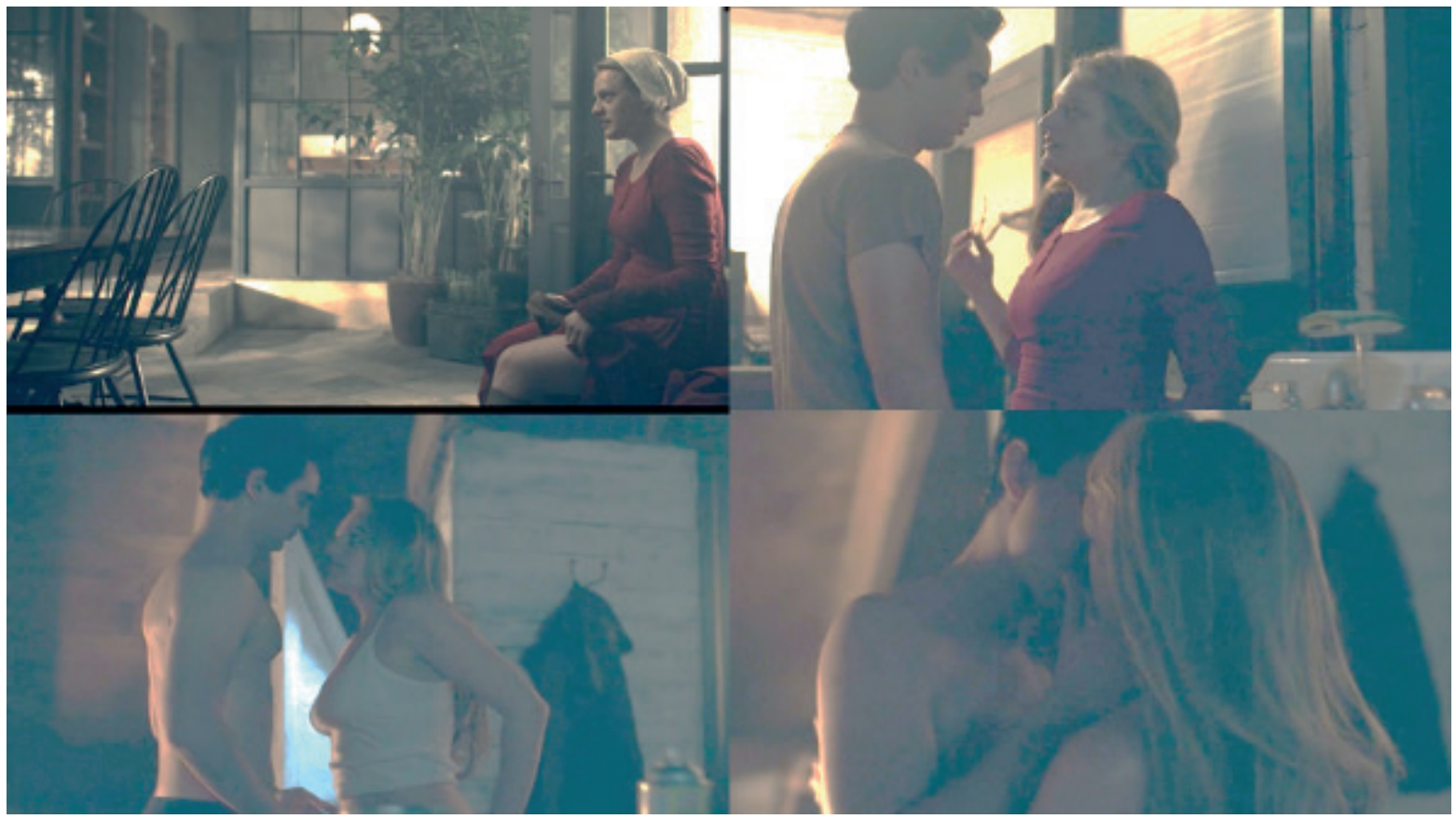

Fonte: THE HANDMAID’S..., $1^{\text {a }}$ temporada, cenas do episódio 2 e 5 (HULU, 2017).

A SD 10 demonstra os aspectos interditados ao corpo do sujeito mulher representados no discurso fílmico. Na série, o discurso erótico se expressa através do corpo que se desnuda para o ato sexual, pelo uso dos cabelos soltos e pelo toque entre os corpos durante a relaçăo. No quadro 1 da SD 9, através do plano médio, a personagem desvela parte de sua perna para outra pessoa, o personagem Nick. No quadro 4, em plano mais fechado, a personagem se desnuda do seu traje de aia, mostrando seu corpo como expressăo do desejo. Em ambos os quadros, os sentidos de resistência se instauram na transgressăo ao discurso dominante que proíbe a nudez do corpo feminino e estabelece como vestimentas obrigatórias roupas que simbolizam o apagamento desse corpo e, por consequência, do pecado que ele instigaria.

Bataille (1987, p.14) nos lembra que a nudez perturba a ordem individual do ser, desapossando seu corpo para se renovar em uma fusăo "semelhante ao vaivém das ondas que se penetram e se perdem uma na outra". Ela promove um estado de comunicaçăo entre os corpos concretizando o efeito erótico ao destruir a estrutura que fecha o sujeito nele mesmo, e como sujeitos distinto.

No discurso fílmico de $O$ conto da aia, a posiçâo do corpo erótico é materializada pela produçăo de efeitos de desidentificaçáo (PÊCHEUX, 1975 [2014]) com o imaginário produzido pela ideologia dominante representada na obra. A nudez materializa um efeito de transgressấo à moralidade convocada pela ideologia dominante na interpelaçăo do corpo feminino. O gesto de interpretaçăo do sujeito autor inscreve o corpo na memória discursiva da ideologia judaico-cristă. O processo discursivo de resistência se materializa, no discurso fílmico, pela assunçăo do desejo através da nudez do corpo, que ao se despir rompe com o imaginário dominante do corpo feminino. A nudez, nesse caso, produz o efeito leitor de questionamento e de ruptura, que se dá nas falhas do ritual ideológico e dos modos de subjetivaçâo do sujeito. 


\section{PARA UM EFEITO DE CONCLUSÃO}

O conto da Aia aborda as relaçóes de gênero através da problematizaçăo dos aspectos sociais e ideológicos que constituem o corpo do sujeito mulher como modo de subjetivaçâo em processos discursivos de dominaçâo e resistência. Nas versōes literárias e fílmica da obra, analisamos o funcionamento do discurso do/sobre o corpo a partir de dois efeitos de sentido: o do corpo dominando e do corpo resistente.

No livro, a dominaçăo sobre o corpo é representada pelo efeito de sentido de controle, que se caracteriza por uma interdiçăo de suas potencialidades e restringindo novas posiçóes. O processo discursivo de resistência é materializado pelos sentidos outros interditados na rede de memória do corpo dominado, e por mostrar que o assujeitamento do sujeito representado pela personagem năo se dá de forma plena, assim como o discurso. O corpo-resistente, no discurso literário, se encontra na performance entre duas posiçôes: corpo-subsistência e corpo-erótico. No corpo-subsistência os sentidos se encaminham para o ideal da sobrevivência, da manutençăo da vida, da sanidade mental e da quebra da monotonia. No corpo-erótico, os sentidos funcionam na materializaçấo do desejo despertado pela relaçấo com o próprio corpo e com o corpo do outro, despertando os sentidos da sexualidade feminina.

Na série, o funcionamento discursivo da dominaçăo nâo se dá pelo tensionamento com os sentidos de resistência. $O$ efeito de controle prevalece no modo como o corpo é significado, fazendo ressoar os sentidos de submissâo e violência sobre o corpo feminino. O processo de resistência, por sua vez, acontece em relaçăo às duas posiçôes também salientadas pelo discurso literário. Na posiçăo corpo-subsistência, a relaçăo sexual se concretiza pela dissimulaçăo e o fingimento, subvertendo o lugar social estabelecido para o sujeito aia. Já a posiçăo corpo-erótico, no discurso fílmico, convoca os sentidos da nudez como estratégia de rompimento do ritual ideológico e como expressăo do desejo sexual, năo abordando a relaçăo corpo e sujeito, como no literário, mas reclamando ao desnudamento a significaçăo desse processo.

Ao optarmos por analisar as duas obras sabíamos que seria um trabalho complexo e ao mesmo tempo longe de uma conclusâo unificada. Porém, nossa análise consegue mostrar como o discurso fílmico atualiza os sentidos mobilizados pelo literário, năo só pelas condiçóes de produçấo distintas, mas por representar a relaçăo mulher, corpo e poder de modo diferente. Ao denominar como estupro a violência à qual as mulheres săo submetidas, na representaçăo literária, o discurso fílmico explora modos diferentes de discursivizaçăo do sujeito mulher e seu corpo, através do erótico, interpelando os sujeitos leitores à assunçâo de posiçôes sujeito fora do ficcional acerca dessa temática. A série também materializa o funcionamento discursivo da dominaçâo e da resistência de forma menos tensionada que o discurso literário, acentuando a contraidentificaçăo do sujeito mulher ao discurso dominante, abrindo espaço para novos efeitos de identificação do sujeito.

As duas versóes d'O Conto da Aia que investigamos nesse trabalho demonstram diferentes funcionamentos pelos quais o sujeito mulher e seu corpo săo inscritos em um contexto patriarcal. A partir de nossa análise, pudemos assim constatar que o caráter produtivo do poder age sobre o corpo feminino de duas maneiras: exercendo o poder sobre ele (dominaçáo) e ao mesmo tempo atribuindo-lhe poder (possibilidade de resistência). Dessa forma, as posiçôes-sujeito representadas pela personagem Aia 
sâo construídas no tensionamento entre esses dois modos de discursivizaçăo do poder. Tanto no discurso literário quanto fílmico, notamos que o discurso dominante tenta encerrar o sujeito em sua trama, ao mobilizar determinados sentidos, como os da religiăo, para produzir um efeito de submissâo para o corpo e o sujeito mulher, mas que também deixa falhas que possibilitam a esse sujeito processos de resistência. Desse modo, O Conto da Aia se mostra como uma materialidade simbólica capaz de promover a discussăo sobre as formas de controle do/sobre o corpo feminino e sua sexualidade, assim como sobre as relaçóes de gênero construídas na sociedade contemporânea. 


\section{REFERÊNCIAS}

ATWOOD, M. E. O conto da aia. Rio de janeiro: Rocco, 2017.

BARBOSA, M. R.; MATOS, P. M.; COSTA, M. E. Um olhar sobre o corpo: o corpo ontem e hoje. Psicologia e Sociedade, 23(1), pp. 24-34, 2011.

BATAILLE, G. 0 erotismo. Porto Alegre: L\&PM, 1987.

BEAUVOIR, S. O segundo sexo: fatos e mitos. 5. ed. Rio de Janeiro: Nova Fronteira, 2019.

BUTLER, J. Corpos que pesam: sobre os limites discursivos do sexo. In: LOURO, G. L. (org.) 0 corpo educado: pedagogias da sexualidade. Belo Horizonte, Autêntica, 1999, pp. 151-172.

. Problemas de Gênero: feminismo e subversáo da identidade. 11. ed. Rio de Janeiro: Civilizaçâo Brasileira, 2016.

CAMPELLO, E.; SCHMIDT, R. T. Corpo e literatura. Ilha do deserto, Florianópolis, v. 68, n. 2, pp. 09-14, 2015.

DEL PRIORE, M. L. M. Dossiê: a história do corpo. Anais do Museu Paulista, v. 3, pp. 9-26, 1995.

FEDERICI, S. Calibá e a bruxa: mulheres, corpo e acumulaçăo primitiva. Săo Paulo: Elefante, 2017.

FERREIRA, M. C. L. O corpo como materialidade discursiva. REDISCO, v. 3, n. 1, nov. 2013. FOUCAULT, M. Microfísica do poder. Rio de Janeiro: Ediçôes Graal, 1979.

. Vigiar e punir: o nascimento da prisăo. 20. ed. Petrópolis: Vozes, 1987.

. História da sexualidade: a vontade de saber. 13. ed. Rio de Janeiro: Ediçăo Graal, 1988.

ORLANDI, E. P. Por uma teoria discursiva do sujeito. In: ORLANDI, E. P. Discurso em análise: sujeito, sentido e ideologia. 3. ed. Campinas: Pontes Editores, 2016, pp. 213-234.

PÊCHEUX, M. Semântica e discurso: uma crítica à afirmaçāo do óbvio. 5. ed. Campinas: Editora Unicamp, [1975] 2014.

Papel da memória. In: ACHARD, P.; DAVALON, J.; DURAND, J. L.; PECHEUX, M.; ORLANDI, E. P. Papel da memória. 4.ed. Campinas, Săo Paulo: Pontes, [2007] 2015.

. Metáfora e interdiscurso. In: ORLANDI, E.(Org.) Análise de discurso: Michel Pêcheux

- textos escolhidos por Eni Orlandi. Campinas: Pontes Editores, 2016, pp. 151-161.

SCAVONE, L. Nosso corpo nos pertence? Discursos feministas do corpo. Revista Gênero, v. 10, n. 2, pp. 47-62, 1.sem. 2010.

TEDESCHI, L. A. As mulheres e a história: uma introduçâo teórica metodológica. Dourados, Ms: Ed. UFGD, 2012.

THE HANDMAID'S Tale. Direçăo: Bruce Miller. Estados Unidos: HULU, 2017. Disponível em: https://globoplay.globo.com/the-handmaids-tale/t/QDFNw11dPX/. Acesso em: 2 jun. 2019.

Recebido em 19/03/2020

Aceito em 01/07/2020 